\title{
Sprawozdanie z międzynarodowej konferencji naukowej pt. Liturgia i polityka w wiekach średnich: Interdyscyplinarna analiza pozornie sprzecznych fenomenów, Poznań, 21-23 VI 2018 r.
}

W dniach 21-23 czerwca 2018 r. w siedzibie Instytutu Historii Uniwersytetu im. Adama Mickiewicza w Poznaniu miała miejsce międzynarodowa konferencja naukowa pt. Liturgia i polityka w wiekach średnich: Interdyscyplinarna analiza pozornie sprzecznych fenomenów, której organizacji podjęli się Instytut Historii UAM wraz z Instytutem Historycznym Uniwersytetu Warszawskiego oraz The PSALM-Network (Politics, Society, and Liturgy in the Middle Ages). Była to już druga konferencja poświęcona liturgii i polityce. Rok wcześniej, również w Poznaniu, lecz w siedzibie Biblioteki Raczyńskich, miała miejsce pierwsza konferencja liturgiczna, poświęcona twórczości Ernsta H. Kantorowicza ${ }^{1}$.

Zważając na fakt, że wśród uczestników konferencji były osoby przybywające np. ze Stanów Zjednoczonych czy Izraela, otwarcie konferencji nastąpiło późnym popołudniem 21 czerwca. Dr Paweł Figurski oraz dr Marcin Danielewski, główni organizatorzy konferencji, przywitali wszystkich gości oraz nakreślili ideę zorganizowania tejże konferencji. Później głos zabrał gospodarz miejsca obrad, Dyrektor Instytutu Historii UAM w Poznaniu, prof. dr hab. Józef Dobosz. Po krótkim przemówieniu, prof. UW dr hab. Jerzy Pysiak (Uniwersytet Warszawski), wygłosił referat otwierający obrady, który dotyczył liturgii relikwii oraz cudownych uzdrowień królów francuskich (The Liturgy of Relics, the Royal Disease and the Miraculous Healings of

1 Zob.: J. Wojtczak, Sprawozdanie z międzynarodowej konferencji naukowej pt. „Liturgia i polityka w wiekach średnich. Przeoczone dziedzictwo Ernsta H. Kantorowicza”, Poznań 13-14 VII 2017 r., Historia Slavorum Occidentis 16 (2018), nr 1, s. 129-131. 
the Capetian Kings / Liturgia relikwii, królewska choroba oraz cudowne uzdrawianie królów kapetyńskich).

Drugiego dnia obrad przygotowano cztery panele. Pierwszy z nich, zatytułowany Liturgy as the Intellectual Grid - Liturgia jako siatka pojecciowa, otworzyła PhD Rose Walker (The Courtauld Institute of Art in London), która przedstawiła jak wyglądała liturgia we wczesnośredniowiecznej Hiszpanii (Liturgy, Politics and the Apocalypse in Eleventh and Twelfth Century Spain / Liturgia, polityka i apokalipsa w XI - oraz XII-wiecznej Hiszpanii). Następnie, na temacie liturgi i Visio Rudolfi (Liturgy, the Visio Rudolfi, and the Construction of Old Age / Liturgia, Visio Rudolfi i konstruowanie „dawnego wieku”) skupiła się $\mathrm{PhD}$ Amelia Kennedy (Yale University). Ostatni referat w tym panelu zaprezentowała dr hab. Aleksandra Sulikowska (UW), która swoją uwagę skupiła na prawosławnej ikonografii i wyobrażeniu św. Bazylego Wielkiego (He cut the Savior's hand and leg! Literal Meaning and Orthodox Liturgical Icons based on the Iconography of Saint Basil the Great / Zbawicielowi rękę i nogę oderżnat. O dostowności prawostawnej ikonografi liturgicznej na marginesie pewnego wyobrażenia św. Bazylego Wielkiego).

PhD Nathan Chase (University of Notre Dame) rozpocząl drugi panel zatytułowany Liturgy and Framing Political Identity - Liturgia a ksztaltowanie politycznych tożsamości, a jego referat oscylował wokół liturgii w Królestwie Wizygotów (From Arianism to Orthodoxy: The Role of the Rites of Initiation in Uniting the Visigothic Kingdom / Od arianizmu do ortodoksji. Znaczenie rytów inicjacji w zjednoczeniu królestwa Wizygotów). Następnie głos zabrał dr Paweł Figurski (UW), który przedstawił liturgiczne początki państwa polskiego (Liturgy and Early Medieval State Formation: A Polish Case Study / Liturgiczne początki państwa polskiego). Trzeci i zarazem ostatni referat w tym panelu wygłosiła $\mathrm{PhD}$ Nina Fiches (University of Bristol), która zaprezentowała problem tworzenia się chrześcijańskiej tożsamości na Wyspach Brytyjskich za pomocą legend arturiańskich (The use of Religion in the manuscript Of Arthour and Merlin: The creation and promotion of a Christian English identity through the Arthurian Legend / Rola religii w rękopisie Of Arthour and of Merlin. Tworzenie i promowanie chrześcijańskiej tożsamości Anglików za pomoca arturiańskich legend).

Liturgy and Rituals of Power - Liturgia a rytualy wtadzy - taką nazwę nosił trzeci panel, który otworzyła Prof. Iris Shagrir (The Open University of Israel), która przedstawiła rolę liturgii w dwunastowiecznej Jerozolimie (Liturgy and the Latin Renovatio of Jerusalem in the Twelfth century / Liturgia i łacinska renovatio Jerozolimy w XII wieku). Po niej głos zabrał dr Bartłomiej Dźwigała (Uniwersytet Kardynała 
Stefana Wyszyńskiego w Warszawie), który przybliżył historię relikwii Krzyża Świętego (Relics of the Holy Cross in the Kingdom of Jerusalem. Liturgy and politics / Relikwie Krzyża świętego w Królestwie Jerozolimskim. Liturgia i polityka). Następnie, $\mathrm{PhD}$ Constantin Cless (Yale University) przedstawił, jak wyglądała wojna psychologiczna podczas bitwy pod Lincoln (The Poore-Treasurers Pay Their Debts: Psychological Warfare in the Battle of Lincoln / Biedni skarbnicy ptaca swoje dtugi. Wojna psychologiczna podczas bitwy pod Lincoln).

Czwarty i zarazem ostatni panel w tym dniu został zatytułowany Liturgy and Royal Coronations - Liturgia i królewskie koronacje. Pierwszy z prelegentów, prof. dr hab. Zbigniew Dalewski (Instytut Historii im. Tadeusza Manteuffla Polskiej Akademii Nauk), przedstawił problem liturgii podczas koronacji Piastów (Liturgy and Politics: Coronations of Piasts / Liturgia i polityka: piastowskie koronacje). Drugi prelegent, prof. dr hab. Edward Skibiński (UAM), przeanalizował, jak mogła wyglądać koronacja pierwszego króla Polski (Coronation of Bolesław the Brave / Koronacja Bolesława Chrobrego). Po zakończeniu obrad wszystkich zgromadzonych gości zaproszono na uroczystą kolację.

Ostatniego dnia konferencji mieliśmy możliwość wysłuchać trzech referatów wygłoszonych w panelu Liturgy of Medieval Poland - Liturgia w średniowiecznej Polsce. Pierwszy prelegent, dr Grzegorz Pac (UW), w swoim referacie skupił się na osobie św. Gertrudy (Gertrude and Saints. Female Devotion Between the East and the West / Gertruda i święci. Kobieca dewocja między Wschodem a Zachodem). Następnie nad artystycznym i symbolicznym aspektem ewangeliarzy (Codices Aurei as the artistic and symbolic representation of Christ's Eternal Government / Pisane złotem ewangeliarze jako artystyczny i symboliczny obraz wiecznego królowania Chrystusa) skupił się prof. dr hab. Leszek Wetesko (UAM). Referentem zamykającym obrady był prof. dr hab. Józef Dobosz (UAM), który przybliżył zgromadzonym rolę Kościoła w Poznaniu we wczesnym średniowieczu (Ruler and the Church in early medieval Poznań Settlement, ca. 900 - ca. 1300 / Wtadca i Kościót w poznańskim zespole osadniczym we wcześniejszym średniowieczu, X-XIII wiek).

Uroczystego zamknięcia konferencji dokonał gospodarz Instytutu Historii UAM, a organizatorzy: dr Paweł Figurski i dr Marcin Danielewski dokonali oficjalnego podsumowania. W najbliższym czasie możemy się spodziewać publikacji pokonferencyjnej, a za rok kolejnej edycji konferencji liturgicznej. 
mgr Jakub Wojtczak

Instytut Historii

Wydział Historyczny

Uniwersytet im. Adama Mickiewicza

ul. Umultowska 89d

61-614 Poznań

kub.wojtczak@gmail.com 